\title{
Landscape Evaluation of Rural and Small Towns in Siming Mountain of Zhejiang Based on Landscape Performance
}

\author{
Miao Yang ${ }^{1, *}$, Yang Zhao ${ }^{1}$, and Tiezheng Zhao $^{1}$ \\ ${ }^{1}$ Urban planning and design, Shanghai Institute of Technology, 200234 Shanghai Institute of Technology, China
}

\begin{abstract}
With the advancement of China's urbanization process, China's villages and small towns also begin to face a series of challenges such as ecological environment destruction, population outflow and aging. In order to better deal with these challenges, Zhejiang province issued the "Interim Measures for the Assessment and Acceptance of Environmental Comprehensive Improvement Actions in Small Towns in Zhejiang Province". The document provides detailed environmental assessments of villages and small towns, but lacks economic and social assessments. This study introduced the performance evaluation system of landscape, it focuses on the sustainable development of the thought and the advantage of quantitative evaluation system, combined with"Interim Measures for the Assessment and Acceptance of Environmental Comprehensive Improvement Actions in Small Towns in Zhejiang Province", to build a strong comprehensive evaluation index system. Then, the analytic hierarchy process (AHP) and fuzzy comprehensive evaluation method (FCE) are used to draw the conclusion. In this way, the direction of key construction in the next step of rural and small town development can be clarified to achieve better development of this region.
\end{abstract}

\section{Background}

In recent years, China's rapid urbanization has caused serious social and environmental problems in rural and small towns in China. At the same time, due to weak environmental protection awareness of rural and small town residents, insufficient government investment in environmental governance and insufficient supervision, the ecological environment of rural and small towns in China is deteriorating. In order to solve these problems, Zhejiang Province promulgated the "Interim Measures for the Assessment and Acceptance of Environmental Comprehensive Improvement Actions in Small Towns in Zhejiang Province" in 2018. Some of the content also applies to villages. It mainly evaluates the landscape and environment of villages and small towns, and the assessment is rich in content, which fits the actual construction situation of villages and small towns and has strong pertinence. [1] However, the evaluation indicators of this set of assessment methods are difficult to quantify, and there is a lack of evaluation on the economic and social levels.

The theory of Landscape Performance is based on three aspects: environment, economy and society. By quantifying the environmental, economic and social benefits of the completed landscape project (mainly referring to the urban park green space), the performance of the project can be clarified, so as to determine whether the design methods and strategies meet the design objectives and contribute to the sustainable development of the project. [2] This evaluation system not only meets the requirements of sustainable development, but also has a quantifiable calculation toolbox. However, some of the evaluation indicators are too micro, which do not fit well with the actual construction of rural and small towns in China.

\section{Construction of index system}

\subsection{Selection of Indicators for "Interim Measures for the Assessment and Acceptance of Environmental Comprehensive Improvement Actions in Small Towns in Zhejiang Province"}

The “ Interim Measures for the Assessment and Acceptance of Environmental Comprehensive Improvement Actions in Small Towns in Zhejiang Province" is dedicated to improving the landscape and environment of rural and small towns and improving the functions of towns. Its assessment and evaluation methods are mainly field research. This evaluation index has a strong pertinence to Siming mountain villages and small towns in eastern Zhejiang province..

\footnotetext{
* Corresponding author: 1778503125@qqu.com
} 
Table 1. Evaluation Indicators of "Interim Measures for the Assessment and Acceptance of Environmental Comprehensive Improvement Actions in Small Towns in Zhejiang Province"

\begin{tabular}{|c|c|}
\hline \multirow{4}{*}{$\begin{array}{c}\text { First Level } \\
\text { Environmental } \\
\text { improvement }\end{array}$} & Second Level \\
\cline { 2 - 2 } & Keep water clean \\
\hline \multirow{4}{*}{$\begin{array}{c}\text { Improvement of town } \\
\text { style }\end{array}$} & Road occupied \\
\cline { 2 - 2 } & Unordered parking \\
\cline { 2 - 2 } & Demolition of illegal houses \\
\cline { 2 - 2 } & Wire arrangement at random \\
\cline { 2 - 2 } & $\begin{array}{c}\text { Street elevation } \\
\text { improvement }\end{array}$ \\
\cline { 2 - 2 } & $\begin{array}{c}\text { Promote the integration of } \\
\text { renewable energy buildings }\end{array}$ \\
\hline \multirow{5}{*}{$\begin{array}{c}\text { Landscape enhancement } \\
\text { Improve supporting facilities }\end{array}$} \\
\cline { 2 - 2 } Enhance landscape greening \\
\hline \multirow{5}{*}{$\begin{array}{c}\text { Extra points } \\
\text { Resident satisfaction }\end{array}$} \\
\cline { 2 - 2 } & $\begin{array}{c}\text { Protection of historical and } \\
\text { cultural blocks and historic } \\
\text { buildings }\end{array}$ \\
\cline { 2 - 2 } & $\begin{array}{c}\text { Local characteristic } \\
\text { residential renovation }\end{array}$ \\
\hline
\end{tabular}

\subsection{Selection of Landscape Performance Evaluation Index}

Landscape Performance is an assessment of the operational status of completed projects, which in the United States are parklands. The current research results have covered 7 categories of assessment indicators: land, water, habitat, carbon, energy and air quality, materials and waste, economics and society. [2] The scope of this study is the rural areas and small towns of Siming Mountain in eastern Zhejiang. It has certain differences in scale and nature from the green space of American city parks. Therefore, some indicators of Landscape Performance need to be deleted.

Table 2. Landscape Performance Evaluation Index.

\begin{tabular}{|c|c|c|}
\hline First Level & Second Level & Third Level \\
\hline \multirow{7}{*}{$\begin{array}{l}\text { Economic } \\
\text { performance }\end{array}$} & \multirow[t]{2}{*}{ Real estate value } & Housing sales price \\
\hline & & House rental fee \\
\hline & $\begin{array}{c}\text { Construction cost } \\
\text { savings }\end{array}$ & $\begin{array}{l}\text { Save money by } \\
\text { reusing materials }\end{array}$ \\
\hline & Job & $\begin{array}{l}\text { Number of jobs } \\
\text { created }\end{array}$ \\
\hline & \multirow{2}{*}{$\begin{array}{c}\text { Tourist } \\
\text { consumption } \\
\end{array}$} & Site rental fee \\
\hline & & Ticket income \\
\hline & $\begin{array}{l}\text { Economic } \\
\text { Growth }\end{array}$ & Parking revenue \\
\hline \multirow{6}{*}{$\begin{array}{c}\text { Social } \\
\text { performance }\end{array}$} & \multirow{2}{*}{$\begin{array}{l}\text { Recreation and } \\
\text { Social Value }\end{array}$} & Visitors \\
\hline & & Tourist satisfaction \\
\hline & $\begin{array}{l}\text { Cultural } \\
\text { protection }\end{array}$ & $\begin{array}{c}\text { Number of ancient } \\
\text { trees }\end{array}$ \\
\hline & $\begin{array}{l}\text { Healthy and } \\
\text { quality life }\end{array}$ & type of activity \\
\hline & \multirow{2}{*}{$\begin{array}{l}\text { Landscape } \\
\text { quality }\end{array}$} & Satisfaction \\
\hline & & Infrastructure quality \\
\hline
\end{tabular}

\begin{tabular}{|c|c|c|}
\hline \multirow{4}{*}{} & Traffic & Traffic flow quality \\
\cline { 3 - 3 } & & $\begin{array}{c}\text { Walking system } \\
\text { quality }\end{array}$ \\
\cline { 3 - 3 } & & $\begin{array}{c}\text { Quality of public } \\
\text { transportation }\end{array}$ \\
\hline $\begin{array}{c}\text { Ecological } \\
\text { performance }\end{array}$ & Water & $\begin{array}{c}\text { Water quality } \\
\text { monitoring data }\end{array}$ \\
\cline { 2 - 3 } & Habitat & Green coverage \\
\cline { 2 - 3 } & air & PM2.5 reduction \\
\cline { 2 - 3 } & Material reuse & $\begin{array}{c}\text { Recycled material as } \\
\text { a percentage of total } \\
\text { material }\end{array}$ \\
\hline
\end{tabular}

\subsection{Establishment of post-construction evaluation index based on Landscape Performance of Siming mountain village and small town in eastern Zhejiang province}

According to the research and analysis of the two evaluation systems mentioned above. This evaluation system takes the first-level indicators in the Landscape Performance evaluation system: social performance, economic performance, and ecological performance as the overall framework, and combines some indicators of Evaluation Indicators of "Interim Measures for the Assessment and Acceptance of Environmental Comprehensive Improvement Actions in Small Towns in Zhejiang Province". [3] The author establishes a postevaluation system for rural and small town construction in Siming Mountain, eastern Zhejiang based on Landscape Performance.

Table 3. Post-construction Evaluation Index of Siming mountain village and small town in eastern Zhejiang based on Landscape Performance

\begin{tabular}{|c|c|c|}
\hline First Level & Second Level & Third Level \\
\hline \multirow{7}{*}{$\begin{array}{c}\text { Economic } \\
\text { performance }\end{array}$} & \multirow[t]{2}{*}{ Real estate value } & Housing sales price \\
\hline & & House rental fee \\
\hline & Job & $\begin{array}{c}\text { Number of jobs } \\
\text { created }\end{array}$ \\
\hline & \multirow{3}{*}{$\begin{array}{c}\text { Tourist } \\
\text { consumption }\end{array}$} & Site rental fee \\
\hline & & Visitors \\
\hline & & Ticket income \\
\hline & $\begin{array}{l}\text { Economic } \\
\text { Growth }\end{array}$ & Parking revenue \\
\hline \multirow{8}{*}{$\begin{array}{c}\text { Social } \\
\text { performance }\end{array}$} & Relevant policy & Resident satisfaction \\
\hline & \multirow[t]{4}{*}{ Cultural } & $\begin{array}{l}\text { Number of ancient } \\
\text { trees }\end{array}$ \\
\hline & & $\begin{array}{c}\text { Protection of } \\
\text { historical and cultural } \\
\text { blocks and historic } \\
\text { buildings }\end{array}$ \\
\hline & & $\begin{array}{l}\text { Local characteristic } \\
\text { residential renovation }\end{array}$ \\
\hline & & Type of activity \\
\hline & \multirow[t]{3}{*}{ Traffic } & Traffic flow quality \\
\hline & & $\begin{array}{c}\text { Walking system } \\
\text { quality }\end{array}$ \\
\hline & & $\begin{array}{l}\text { Quality of public } \\
\text { transportation }\end{array}$ \\
\hline Ecological & Ecosystem & Water quality \\
\hline
\end{tabular}




\begin{tabular}{|c|c|c|}
\hline performance & monitoring data \\
\cline { 3 - 3 } & & PM2.5 reduction \\
\cline { 3 - 3 } & $\begin{array}{c}\text { Recycled material as a } \\
\text { percentage of total } \\
\text { material }\end{array}$ \\
\cline { 3 - 3 } & $\begin{array}{c}\text { Renewable energy } \\
\text { efficiency }\end{array}$ \\
\cline { 3 - 3 } & $\begin{array}{c}\text { Landscape } \\
\text { environment }\end{array}$ & Green coverage \\
\cline { 3 - 3 } & Landscape satisfaction \\
& Street environment \\
\cline { 3 - 3 } & $\begin{array}{c}\text { Community } \\
\text { environment }\end{array}$ \\
\hline
\end{tabular}

\section{Research methods}

At present, the commonly used systematic evaluation methods include fuzzy comprehensive evaluation method and analytic hierarchy process. Since the comments used in the post-construction evaluation are often vague, it is advisable to adopt a fuzzy comprehensive evaluation method. Using this evaluation method, the weight of each index has a decisive position, and the weight of fuzzy evaluation is usually given by experts based on experience, which is inevitably subjective. Analytic Hierarchy Process (AHP) is a method that combines quantitative and qualitative methods to express and process human subjective judgments in quantitative form. It can minimize the impact of personal subjective judgments and make the evaluation results more credible. [4]

In this study, two systematic evaluation methods were used to evaluate typical cases. The author attempts to further clarify the key direction of relevant cases in the future development through the evaluation results.

\section{Case study: Fengcun}

Fengcun is located in Siming Mountain, Yuyao, Zhejiang. It is 5 kilometers from Lanjiang Street and 10 kilometers from the urban area, covering an area of 7.5 square kilometers. The area of the hills in the village area is large, the water resources in the village are rich, and the vegetation is in good condition.

Fengcun compiled "the Village Planning of Fengcun (Zhu Feng Village) of Lanjiang Street in Yuyao City" and "the Village Design of Fengcun (Zhu Feng Village) of Lanjiang Street in Yuyao City" in 2017. The project covers an area of 7.5 square kilometers. It focuses on sorting out the road traffic in Fengcun and guiding the landscape of Fengcun.

Through field investigation and questionnaire distribution, the author made an evaluation and analysis on Fengcun by combining AHP and fuzzy comprehensive evaluation method, and reached the following conclusions (as shown in Table 4).

Since there is no real estate project development and construction in Fengcun, the index of real estate value is not applicable to the actual situation of construction in Fengcun. Therefore, this index is deleted.
Through field investigation and data comparison, it can be found that in the evaluation of Fengcun Construction, the economic performance score was 10.615 , the social performance score was 8.067, and the ecological performance score was 23.62. Ecological performance is better than economic performance, and economic performance is better than social performance. Therefore, in the future development of Fengcun, more attention should be paid to the construction of public transportation, public infrastructure, historical and cultural protection and utilization.

\section{Conclusions}

The evaluation system constructed in this study has strong regional specificity, and also combines the results of foreign research. The two evaluation systems at home and abroad complement each other and have a broader horizon. It is conducive to rural and small towns to supplement and improve the next stage of strategic research through the summary.

Secondly, although some data were obtained in this study, the evaluation of some indicators lacks dynamic tracking, which has a certain impact on the evaluation of the results.

Finally, the major difficulty of future research lies in the acquisition of large amounts of data and the processing of non-quantitative data.

\section{Analysis and discussion}


Table 4. Post-construction Evaluation of Fengcun

\begin{tabular}{|c|c|c|c|c|c|c|c|c|c|c|c|c|}
\hline \multicolumn{3}{|c|}{$\begin{array}{l}\text { Post-construction evaluation index of } \\
\text { Siming mountain village and small } \\
\text { town in eastern Zhejiang based on } \\
\text { landscape performance }\end{array}$} & \multirow[t]{2}{*}{$\begin{array}{l}\text { Implementati } \\
\text { on effect }\end{array}$} & \multicolumn{2}{|c|}{ Weights } & \multicolumn{4}{|c|}{ Classification } & \multirow{2}{*}{\multicolumn{3}{|c|}{ Score }} \\
\hline First Level & $\begin{array}{l}\text { Second } \\
\text { Level }\end{array}$ & Third Level & & & & $\begin{array}{c}\text { Best } \\
(+2 \\
)\end{array}$ & $\begin{array}{l}\text { Better } \\
(+1 \\
)\end{array}$ & $\begin{array}{l}\text { Gener } \\
\text { al } \\
(0)\end{array}$ & $\begin{array}{c}\mathrm{Ba} \\
\mathrm{d} \\
(- \\
1 \\
)\end{array}$ & & & \\
\hline \multirow[t]{5}{*}{$\begin{array}{l}\text { Economic } \\
\text { performan } \\
\text { ce }\end{array}$} & Job & $\begin{array}{l}\text { Number of } \\
\text { jobs created }\end{array}$ & $\begin{array}{l}\text { The tertiary } \\
\text { industry has } \\
\text { developed, } \\
\text { and the } \\
\text { number of } \\
\text { jobs has } \\
\text { increased } \\
\text { significantly }\end{array}$ & $\begin{array}{c}0.27 \\
0\end{array}$ & $\begin{array}{c}1.00 \\
0\end{array}$ & 4 & 10 & 4 & 2 & $\begin{array}{l}1 \\
6\end{array}$ & $\begin{array}{c}16.0 \\
0\end{array}$ & $\begin{array}{l}10 \\
.6 \\
15\end{array}$ \\
\hline & \multirow{3}{*}{$\begin{array}{l}\text { Tourist } \\
\text { consumpti } \\
\text { on }\end{array}$} & $\begin{array}{l}\text { Site rental } \\
\text { fee }\end{array}$ & $\begin{array}{c}\text { Slight } \\
\text { increase }\end{array}$ & \multirow[t]{3}{*}{$\begin{array}{c}0.35 \\
0\end{array}$} & $\begin{array}{c}0.33 \\
0 \\
\end{array}$ & 2 & 8 & 6 & 4 & 8 & \multirow[t]{3}{*}{9.30} & \\
\hline & & Visitors & $\begin{array}{l}\text { The number } \\
\text { of tourists } \\
\text { has increased } \\
\text { significantly }\end{array}$ & & $\begin{array}{c}0.33 \\
0\end{array}$ & 3 & 11 & 3 & 3 & $\begin{array}{l}1 \\
4\end{array}$ & & \\
\hline & & $\begin{array}{l}\text { Ticket } \\
\text { income }\end{array}$ & $\begin{array}{c}\text { Slight } \\
\text { increase }\end{array}$ & & $\begin{array}{c}0.34 \\
0\end{array}$ & 2 & 7 & 6 & 5 & 6 & & \\
\hline & $\begin{array}{l}\text { Economic } \\
\text { Growth }\end{array}$ & $\begin{array}{l}\text { Parking } \\
\text { revenue }\end{array}$ & $\begin{array}{c}\text { Slight } \\
\text { increase }\end{array}$ & $\begin{array}{c}0.38 \\
0\end{array}$ & $\begin{array}{c}1.00 \\
0\end{array}$ & 2 & 8 & 6 & 4 & 8 & 8.00 & \\
\hline \multirow{8}{*}{$\begin{array}{l}\text { Social } \\
\text { performan } \\
\text { ce }\end{array}$} & $\begin{array}{c}\text { Relevant } \\
\text { policy }\end{array}$ & $\begin{array}{c}\text { Resident } \\
\text { satisfaction }\end{array}$ & $\begin{array}{c}\text { High } \\
\text { satisfaction }\end{array}$ & $\begin{array}{c}0.32 \\
0\end{array}$ & $\begin{array}{c}1.00 \\
0\end{array}$ & 4 & 12 & 4 & 0 & $\begin{array}{l}1 \\
6\end{array}$ & $\begin{array}{c}16.0 \\
0\end{array}$ & $\begin{array}{l}8 . \\
06\end{array}$ \\
\hline & \multirow[t]{4}{*}{ Cultural } & $\begin{array}{l}\text { Number of } \\
\text { ancient } \\
\text { trees }\end{array}$ & $\begin{array}{c}\text { Ancient trees } \\
\text { are numerous } \\
\text { and } \\
\text { effectively } \\
\text { protected }\end{array}$ & \multirow[t]{4}{*}{$\begin{array}{c}0.33 \\
0\end{array}$} & $\begin{array}{c}0.25 \\
0\end{array}$ & 8 & 8 & 4 & 0 & $\begin{array}{l}2 \\
4\end{array}$ & \multirow[t]{4}{*}{8.25} & \multirow[t]{7}{*}{7} \\
\hline & & $\begin{array}{l}\text { Protection } \\
\text { of historical } \\
\text { and cultural } \\
\text { blocks and } \\
\text { historic } \\
\text { buildings }\end{array}$ & $\begin{array}{l}\text { There is no } \\
\text { preservation } \\
\text { of historic } \\
\text { buildings }\end{array}$ & & $\begin{array}{c}0.25 \\
0\end{array}$ & 0 & 2 & 12 & 6 & -2 & & \\
\hline & & $\begin{array}{c}\text { Local } \\
\text { characterist } \\
\text { ic } \\
\text { residential } \\
\text { renovation }\end{array}$ & $\begin{array}{c}\text { There is no } \\
\text { large-scale } \\
\text { transformatio } \\
\mathrm{n} \text { and } \\
\text { utilization of } \\
\text { traditional } \\
\text { dwellings }\end{array}$ & & $\begin{array}{c}0.25 \\
0\end{array}$ & 0 & 2 & 12 & 6 & -2 & & \\
\hline & & $\begin{array}{l}\text { Type of } \\
\text { activity }\end{array}$ & $\begin{array}{c}\text { Increase } \\
\text { significantly }\end{array}$ & & $\begin{array}{c}0.25 \\
0\end{array}$ & 3 & 9 & 6 & 2 & $\begin{array}{l}1 \\
3\end{array}$ & & \\
\hline & \multirow[t]{3}{*}{ Traffic } & $\begin{array}{l}\text { Traffic } \\
\text { flow } \\
\text { quality }\end{array}$ & $\begin{array}{c}\text { Slight } \\
\text { increase }\end{array}$ & $\begin{array}{c}0.35 \\
0\end{array}$ & $\begin{array}{c}0.34 \\
0\end{array}$ & 0 & 3 & 15 & 2 & 1 & \multirow[t]{3}{*}{0.64} & \\
\hline & & $\begin{array}{l}\text { Walking } \\
\text { system } \\
\text { quality }\end{array}$ & $\begin{array}{c}\text { Slight } \\
\text { increase }\end{array}$ & & $\begin{array}{c}0.32 \\
0\end{array}$ & 0 & 5 & 12 & 3 & 2 & & \\
\hline & & $\begin{array}{l}\text { Quality of } \\
\text { public } \\
\text { transportati } \\
\text { on }\end{array}$ & $\begin{array}{l}\text { Nothing } \\
\text { much has } \\
\text { changed }\end{array}$ & & $\begin{array}{c}0.34 \\
0\end{array}$ & 0 & 2 & 15 & 3 & -1 & & \\
\hline \multirow[t]{2}{*}{$\begin{array}{l}\text { Ecological } \\
\text { performan } \\
\text { ce }\end{array}$} & \multirow[t]{2}{*}{ Ecosystem } & $\begin{array}{c}\text { Water } \\
\text { quality } \\
\text { monitoring } \\
\text { data }\end{array}$ & $\begin{array}{l}\text { Nothing } \\
\text { much has } \\
\text { changed }\end{array}$ & $\begin{array}{c}0.57 \\
0\end{array}$ & $\begin{array}{c}0.25 \\
0\end{array}$ & 4 & 12 & 4 & 0 & $\begin{array}{l}2 \\
0\end{array}$ & \multirow[t]{2}{*}{$\begin{array}{c}19.2 \\
5\end{array}$} & \multirow[t]{2}{*}{$\begin{array}{l}23 \\
.6 \\
2\end{array}$} \\
\hline & & $\begin{array}{l}\text { PM2.5 } \\
\text { reduction }\end{array}$ & $\begin{array}{l}\text { Nothing } \\
\text { much has }\end{array}$ & & $\begin{array}{c}0.25 \\
0\end{array}$ & 6 & 10 & 4 & 0 & $\begin{array}{l}2 \\
2\end{array}$ & & \\
\hline
\end{tabular}




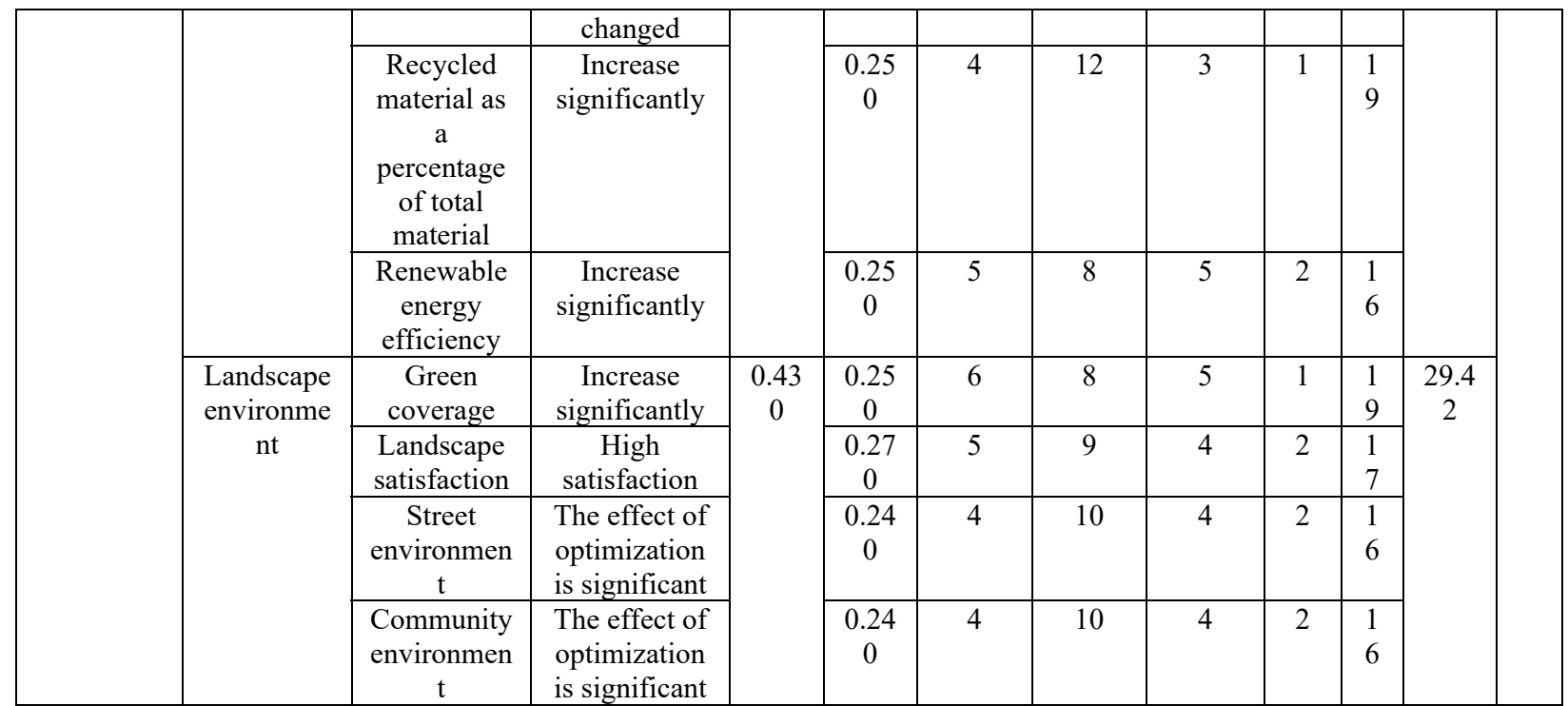

\section{References}

1. Zhejiang Government. "Interim Measures for the Assessment and Acceptance of Environmental Comprehensive Improvement Actions in Small Towns in Zhejiang Province". (2018)

2. Tang Da. Research with Respect to Conservation of Jinci Garden Based on Landscape Performance Evaluation.Shanxi Taiyuan: Taiyuan University of Technology;(2019)

3. Zhao T, Zhao Y,Li M. Landscape Performance for Coordinated Development of Rural Communities \& Small-Towns Based on "Ecological Priority and AllArea Integrated Development": Six Case Studies in East China's Zhejiang Province. Sustainability.11(2019)

4. Han L,Mei Q,Lu Y,Ji M.Analysis and Study on AHP-Fuzzy Comprehensive Evaluation.China Safety Science Journal.14(2014)

5. $\mathrm{Xu} \mathrm{Yaru}, \mathrm{Fu}$ Zhiqing.A Review of American Landscape Performance in 2010-2016. Proceedings of the 2017 Conference of the Chinese Society of Landscape Architecture.(2017)

6. Li C,Liu S,Liang Jun.Review on Landscape Performance Series Benefit Tooklit in America. Proceedings of the 2016 Conference of the Chinese Society of Landscape Architecture.(2016)

7. Luo Y,Li M,Duan S. Landscape Performance of Built Projects: Comparing Landscape Architecture Foundation's Published Metrics and Methods. Landscape Architecture. 1 (2015)

8. Sun N,Luo Y,Li M.quantification of Landscape Performance for Built Projects through LAF Landscape Performance Series. Proceedings of the 2013 Conference of the Chinese Society of Landscape Architecture.(2013)

9. Zhao T, Zhao Y. the Village Design of Fengcun (Zhu Feng Village) of Lanjiang Street in Yuyao City.(2017)
10. Zhao T, Zhao Y. the Village Planning of Fengcun (Zhu Feng Village) of Lanjiang Street in Yuyao City.(2017) 